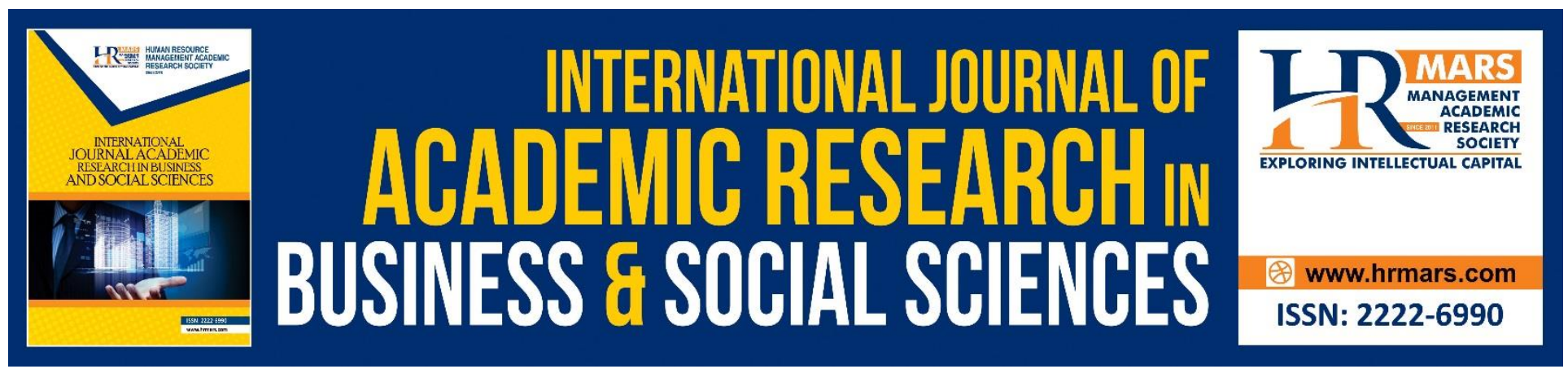

\title{
Marketing Outsourcing and Performance of Commercial Banks in Kenya
}

Isaiah Muriithi Gituma, Linda Kimencu, Anne Muchemi

To Link this Article: http://dx.doi.org/10.6007/IJARBSS/v8-i12/5243 DOI: $10.6007 /$ IJARBSS/v8-i12/5243

Received: 21 Oct 2018, Revised: 29 Nov 2018, Accepted: 29 Dec 2018

Published Online: 31 Dec 2018

In-Text Citation: (Gituma, Kimencu, \& Muchemi, 2018)

To Cite this Article: Gituma, I. M., Kimencu, L., \& Muchemi, A. (2018). Marketing Outsourcing and Performance of Commercial Banks in Kenya. International Journal of Academic Research in Business and Social Sciences, 8(12), 1402-1421.

Copyright: (C) 2018 The Author(s)

Published by Human Resource Management Academic Research Society (www.hrmars.com)

This article is published under the Creative Commons Attribution (CC BY 4.0) license. Anyone may reproduce, distribute, translate and create derivative works of this article (for both commercial and non-commercial purposes), subject to full attribution to the original publication and authors. The full terms of this license may be seen

at: http://creativecommons.org/licences/by/4.0/legalcode

Vol. 8, No. 12, 2018, Pg. 1402 - 1421

http://hrmars.com/index.php/pages/detail/IJARBSS

JOURNAL HOMEPAGE

Full Terms \& Conditions of access and use can be found at http://hrmars.com/index.php/pages/detail/publication-ethics 


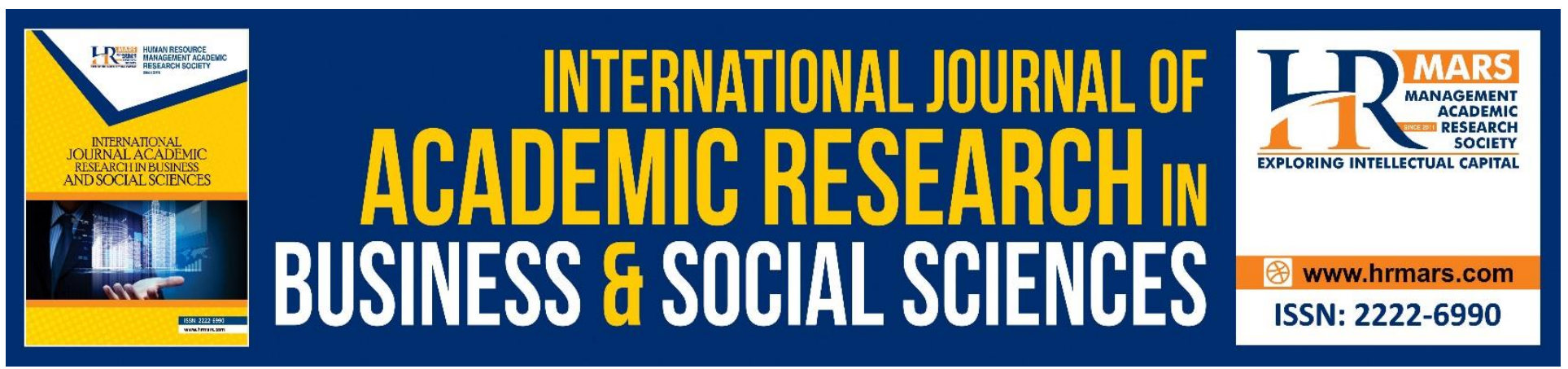

\title{
Marketing Outsourcing and Performance of Commercial Banks in Kenya
}

\author{
Isaiah Muriithi Gituma \\ (Corresponding Author) \\ PhD student, Kenyatta University, Nairobi - Kenya \\ Email:mgituma2013@gmail.com \\ Dr. Linda Kimencu \\ Kenyatta University, Nairobi - Kenya \\ Dr. Anne Muchemi \\ Kenyatta University, Nairobi - Kenya
}

\begin{abstract}
Marketing of banking product offerings is an emerging phenomenon that has potential effect on performance of commercial banks especially in the prevailing situation where globally, the banking sector is struggling to bounce bank to positive performance since the 2007-2008 global financial crunch. In Kenya, commercial banks are facing performance challenges as evidenced by recent assumption of cost rationalization measures such as staff lay-offs and closure of redundant branches; acquisition, liquidation and statutory management of some due to liquidity problems. Despite appropriation of different strategies to mitigate the performance challenges, commercial banks continue to struggle to have sustainable performance. This study sought to establish the effect of marketing outsourcing (MO) on performance of commercial banks in Kenya. The study employed cross-sectional explanatory and descriptive research designs. The target population was thirty two commercial banks. Primary data were collected using self-administered questionnaires. Descriptive statistics were computed to describe the characteristics of the study variables while linear regression analysis was used to establish the nature and magnitude of the relationship between the independent and dependent variables. Statistical tests were subjected to 95 per cent level of significance ( $p=\leq 0.05$ ). The study established that outsourcing marketing processes had a statistically significant positive effect on performance of commercial banks in Kenya $(\beta=0.122 ; p=0.000)$. Owing to the findings, the study recommends that commercial banks should develop policies that embed marketing outsourcing
\end{abstract}


INTERNATIONAL JOURNAL OF ACADEMIC RESEARCH IN BUSINESS AND SOCIAL SCIENCES

Vol. 8, No. 12, Dec, 2018, E-ISSN: 2222-6990 @ 2018 HRMARS

strategy in their operations with greater focus on corporate branding which was found to contribute greatly to their performance.

Keywords: Marketing Outsourcing, Bank Performance and Commercial Banks

\section{Introduction}

Outsourcing marketing has become ubiquitous in many corporate organizations and commercial banks are no exception. The adoption of this strategy by commercial banks is largely motivated by numerous performance goals which include but not limited to achieving effectiveness and efficiency, flexibility to respond to the changing demands of a dynamic consumer base, speed, and customer satisfaction as well as improving an organization's bottom-line (Shimamoto \& Redden, 2009; Park, Lee \& Morgan, 2011).

Globally, commercial banks are facing performance sustainability challenges. European Union (EU) banks' profitability remains far lower than in the pre-crisis period (2007-2008) with returns on equity (ROE) falling to $5.4 \%$ in 2016 from $5.7 \%$ in 2015 and non-performing loans (NPLs) rising from $2 \%$ of total loans in 2006 to a peak of $8 \%$ in the Euro area in 2016; net profits in the top three Japanese banks decreased by $8.2 \%$ in 2016 (Bank of China International Institute of Finance, 2017; Ernest \& Young, 2017; KPMG, 2017). Regionally, African commercial banks have continued to register rising levels of NPLs, declining returns on assets (ROA) and returns on equity (ROE) over the past several years (IMF, 2016; BOC IIF, 2017).

In Kenya, commercial banking sector's asset quality (proportion of NPLs to gross loans) deteriorated from 5.6\% in 2014 to $9.2 \%$ in 2016; annualised net interest margins (NIM) fell to $7.1 \%$ in 2017 from $8.9 \%$ in 2016 . Tier 1 (large) commercial banks interest income declined by $9.7 \%$, Tier 2 (medium) declined by $18 \%$ and Tier 3 (small) also declined by 18\%. In 2017, listed commercial banks in the Nairobi Securities Exchange recorded a 13.8\% decline in core earnings per share (EPS) compared to a growth of $15.5 \%$ in 2016 . Local public commercial banks contribution to the sector's total assets declined to $3.9 \%$ in 2016 from $4.5 \%$ in 2015 with that of foreign-owned commercial banks remaining unchanged from 2015 at 30.9\% (Central Bank of Kenya, 2017; AIB Capital Ltd, 2017; Cytonn Investment Ltd., 2017).

\section{The Concept of Marketing Outsourcing}

Marketing outsourcing describe the strategic decision taken by organizations to transfer part of their marketing processes to external vendors with the requisite marketing infrastructure, resources and capabilities in a bid to satisfy customer needs and wants most cost-effectively. Service-based literature places a strong emphasis on the importance of service quality perceptions and the relationship between service quality and customer satisfaction (Taylor \& Baker, 1994). To ensure customer satisfaction, commercial banks need improved customer knowledge, obtained through market research, to develop products and deliver services targeted at specific market segments which result in more directed marketing, sales and service tactics (Datamonitor, 2004). Such market intelligence can be obtained either through in-house market- and marketing research or through the use of the services of experienced marketing vendors. Review of literature shows that commercial banks outsource marketing processes such as corporate branding, promotion, public relations, marketing research, and customer service (Taylor \& Baker, 1994; Alexander, 2012). 
However, despite the attendant benefits of outsourcing marketing processes, $\mathrm{MO}$ is associated with some negative effects which include but not limited to extra costs attributable to vendor selection costs and legal contract costs (Barthélemy \& Geyer, 2005). Researchers also point out that MO can result to loss of management control, loss of intelligent assets, loss of in-house marketing capability, loss of marketing innovative ability, loss of key marketing employees, theft of crucial customer data from banks or sharing of confidential customer information in case of unethical behavior on the part of the vendor, which can adversely affect the credibility of the bank, and loss of the learning curve effect, among others (Park, Lee \& Morgan, 2011; Klien, 1999; Quinn \& Hilmer, 1994). Owing to this ambivalence, this paper sought to establish the effect of marketing outsourcing on the performance of commercial banks in Kenya by testing the following null hypothesis:

$\mathbf{H}_{\mathbf{0}}$ : $\quad$ Marketing outsourcing has no effect on performance of commercial banks in Kenya.

\section{Organizational Performance}

The overarching objective of any organization that is a going-concern is sustainable organizational performance. To achieve this desired objective, organizations invest huge amount of resources in marketing their offerings in a bid to create awareness as well as educate the potential customers on their value proposition. Organizations can use either in-house marketers or outsource select marketing processes to competent marketing vendors in order to leverage on their expertise and experience. However, measuring organization performance is challenging owing to the fact that it is a complex multi-dimensional construct (Kaplan \& Norton, 1996) and more so compounded by the absence of agreement on its measurement indicators among strategic management researchers and scholars (Santos \& Brito, 2012). Most researchers tend to use financial metrics to measure corporate performance (Combs, Crook \& Shook, 2005). However, financial measures only give historical data on organisational performance which may not accurately reflect the future performance of the organisation.

Zuriekat, Salameh and Alrawashdeh (2011) opine that performance can be measured using financial and non-financial indicators; a proposition supported by Kaplan and Norton (1996) in their balanced scorecard model; and Waiganjo, Mukulu and Kahiri (2012) who also argue for wider performance constructs that incorporate aspects of non-financial measures such as effectiveness, efficiency, quality, and company image in addition to financial measures such as profits. From the foregoing arguments, this research adopted the use of the two measures in an attempt to establish the effect of marketing outsourcing on performance of commercial banks in Kenya.

\section{Statement of the Problem}

Despite the efforts being made by commercial banks globally to regain their performance posture since the onset of the 2007-2008 financial crunch, many continue to struggle to attain sustainable performance. In Kenya, the sector's asset quality deteriorated from 5.6\% in 2014 to $9.2 \%$ in 2016 while annualised net interest margins (NIM) fell to $7.1 \%$ in 2017 from $8.9 \%$ in 2016. In 2017, Tier1 (large) commercial banks' interest income declined by $9.7 \%$, Tier 2 (medium) declined by $18 \%$ and Tier 3 (small) also declined by 18\%. In 2017, listed commercial banks in the Nairobi Securities 
INTERNATIONAL JOURNAL OF ACADEMIC RESEARCH IN BUSINESS AND SOCIAL SCIENCES Vol. 8, No. 12, Dec, 2018, E-ISSN: 2222-6990 @ 2018 HRMARS

Exchange recorded a $13.8 \%$ decline in core earnings per share (EPS) compared to a growth of $15.5 \%$ in 2016. Local public commercial banks contribution to the sector's total assets declined to $3.9 \%$ in 2016 from 4.5\% in 2015 with that of foreign-owned commercial banks remaining unchanged from 2015 at 30.9\%. Moreover, rising operational costs have led to staff lay-offs and closure of redundant branches while some commercial banks have been put under receivership, acquisitions or liquidation due to liquidity problems.

Commercial banks in different countries globally have appropriated marketing outsourcing strategy in a bid to manage costs, take advantage of the rich pool of specialised vendors' skills and experience and also to enable them focus on their core business (Park, Lee \& Morgan, 2011; Datamonitor, 2004; Kliem, 1999; Quinn \& Hilmer, 1994). However, most of these banks are found in developed countries like the the US, UK, and emerging economies like China, India, Malaysia and the Philippines, among others (Yang \& Huang, 2010; Kumar, 2005). Literature review showed almost non-existent studies that have focused on outsourcing marketing in the banking sector in Africa and more specifically Kenya. This finding formed the basis of this research; to establish the effect of marketing outsourcing on performance of commercial banks in Kenya; which is a developing country in Africa.

\section{Literature Review}

\section{Theoretical Literature Review}

Marketing outsourcing is supported by a number of theories such as the Core Competence Theory, Resource Based View (RBV) and the Dynamic Capabilities Theory. The Core Competence theory; developed by Prahalad and Hamel (1990), view core competences as capabilities that are central to a firm's value generating activities; assets and skills that are knowledge-based, distinctive, firmspecific and difficult to imitate as they can be formed by using the tangible and intangible value generating resources of the firm. Through outsourcing of selected marketing processes, the management teams and workers of organisations are able to concentrate on their core competencies and hand over non-core functions to outside specialist vendors. By focusing on their core competencies, organisations generate competitive advantage since they perform functions that they are best at (Ljungquist, 2007). Core competence theory suggests that activities should be performed either in-house or by suppliers. Prahalad and Hamel (1990) opine that activities which are not core business of an organisation or/and institution should be considered for outsourcing with best-in-theworld suppliers.

The Resource Based View considers the resources and capabilities of the firm as the source of sustainable competitive advantage which is gained through resources that are valuable, rare, imperfectly imitable, and without strategically equivalent substitutes (Gilley, McGee \& Rasheed, 2004; Mata, Fuerst \& Barney, 1995; Barney, 1991). Moreover, RBV is concerned with the connection between internal resources, strategy and the performance of the organisation (Kiiru, 2015). It focuses on the promotion of sustainable competitive advantage through owning or acquiring strategic resources (human, physical, technological and organisational) and dynamic capabilities. Sustainable performance of an organisation is therefore dependent on its access to strategic resources. Where an organisation lacks key strategic resources, it can acquire them through outsourcing concerned processes to specialist vendors (Ljungquist, 2007). 
The Dynamic Capabilities Theory postulates that sustainable performance of organisations is based on their ability to respond effectively and efficiently to the highly dynamic and hypercompetitive business environment (Teece \& Pisano, 1990, 1994). Teece, Pisano and Shuen (1997) argue that dynamic capabilities are efficient in overcoming the limitations of the RBV by integrating, building, and reconfiguring internal and external competences to address rapidly changing business environments. Researchers have established that improved changes in the abilities of an organisation to cope with the ever changing business environment may reflect positive effects on its performance (Judge, Naoumova \& Douglas, 2009). Consequently, commercial banks are resorting to business process outsourcing strategy to give them the necessary flexibility in areas like marketing, among others.

Owing to the postulations of the foregoing theories, outsourcing select marketing processes is certainly a viable option for any organisation looking to save costs associated with marketing functions. Marketing outsourcing enables management teams to better leverage resources, contain costs, and focus on strategic and value-adding activities. Moreover, close collaboration with specialist marketing vendors reduces the risk of falling behind competitors as the competition landscape changes. The resultant effect for the company that has outsourced marketing processes are benefits from the marketing vendor's specialised expertise, capabilities and resources, thus improving its bottom-line (Glassman, 2000).

\section{Empirical Literature Review: Marketing Processes Outsourcing and Performance}

Results of an empirical study by Chumba, Chepkwony and Tum (2015) on the effect of outsourcing marketing services on performance of manufacturing companies gave a Pearson's Correlation Coefficient value of 0.581 of outsourced marketing activities which was significant at $\alpha=0.01$. These results showed that outsourced marketing activities accounted for $58.1 \%$ of the change in performance thus affirming that outsourced marketing activities have a positive effect on firm performance.

Alexander (2012) examined outsourcing marketing functions in Cluj-Napoca. From a practical point of view, the study's aim was to highlight the way the public relations (PR) services were perceived and used by the economic operators in the city of Cluj-Napoca and their perceptions regarding the outsourcing of PR services. The study was based on mixed research methods in which data were collected and analysed by using quantitative and qualitative tools. The study findings revealed that local operators were involved heavily in public relations activities such as communication with business partners, marketing and brand communication, and media communication. It established that companies still choose to outsource PR services with the main reason being lack of specialists at the expense of financial reasons. The study concluded that the process of outsourcing PR services is seen only as a possible solution for companies to improve their public relations activities and to obtain certain benefits and hence a positive relationship exists between outsourcing of public relations services and performance. The research findings notwithstanding, contextualisation of the study is important in order to compare the results from different study contexts. 
Gannon's (2010) study focused on outsourcing of marketing functions for Small and Medium Enterprises (SMEs). The study's objectives included examining the tools that companies use when making a decision to outsource key areas of their business; the motivating factors to outsource and the implications for companies who outsource marketing functions. The research was a case study and relied on qualitative approach using interview schedules. The study established that the effect of strategic evaluation on an outsourcing operation was found to be indirect rather than direct and concluded that outsourcing of marketing services for SMEs and Medium Enterprises did not have a positive direct effect on their performance. The study was conducted in a different sector. Therefore it would be interesting to examine how results from a different sector such as banking would compare with results from the SME sector and hence the basis of investigating this variable in the Kenyan context and in the commercial banking sector.

Burden \& Li (2005) have also observed that marketing outsourcing has evolved into a viable business solution for any organisation serious about improving its market position, reducing costs, and improving overall quality. This is because it allows such organisations to gain new knowledge, access new markets, establish traction in the industry, reduce the threats and barriers of competition, enhance resource efficiency, and acquire new skills. Outsourcing can also free up valuable resources that, in turn, allow for crucial resource reallocation toward core business activities to better serve organisational goals while providing greater access to leading-edge technology and limiting the focus to core competencies. This strategic management process is informed by the core competencies theory which suggests that certain business activities should be performed either internally or by suppliers (Prahalad \& Hamel, 1990).

From the review of empirical literature, it was difficult to find studies that singularly focused on marketing outsourcing in the banking industry, and more specifically in the commercial banking sector, both in the developed and the developing countries. Most studies that touched on marketing in the outsourcing context only focused on it as sub-variable/indicator of outsourcing in organizations. The absence of compelling studies on the effect of marketing outsourcing on performance in the commercial banking sector provided a gap that this research sought to bridge. 
INTERNATIONAL JOURNAL OF ACADEMIC RESEARCH IN BUSINESS AND SOCIAL SCIENCES Vol. 8, No. 12, Dec, 2018, E-ISSN: 2222-6990 @ 2018 HRMARS

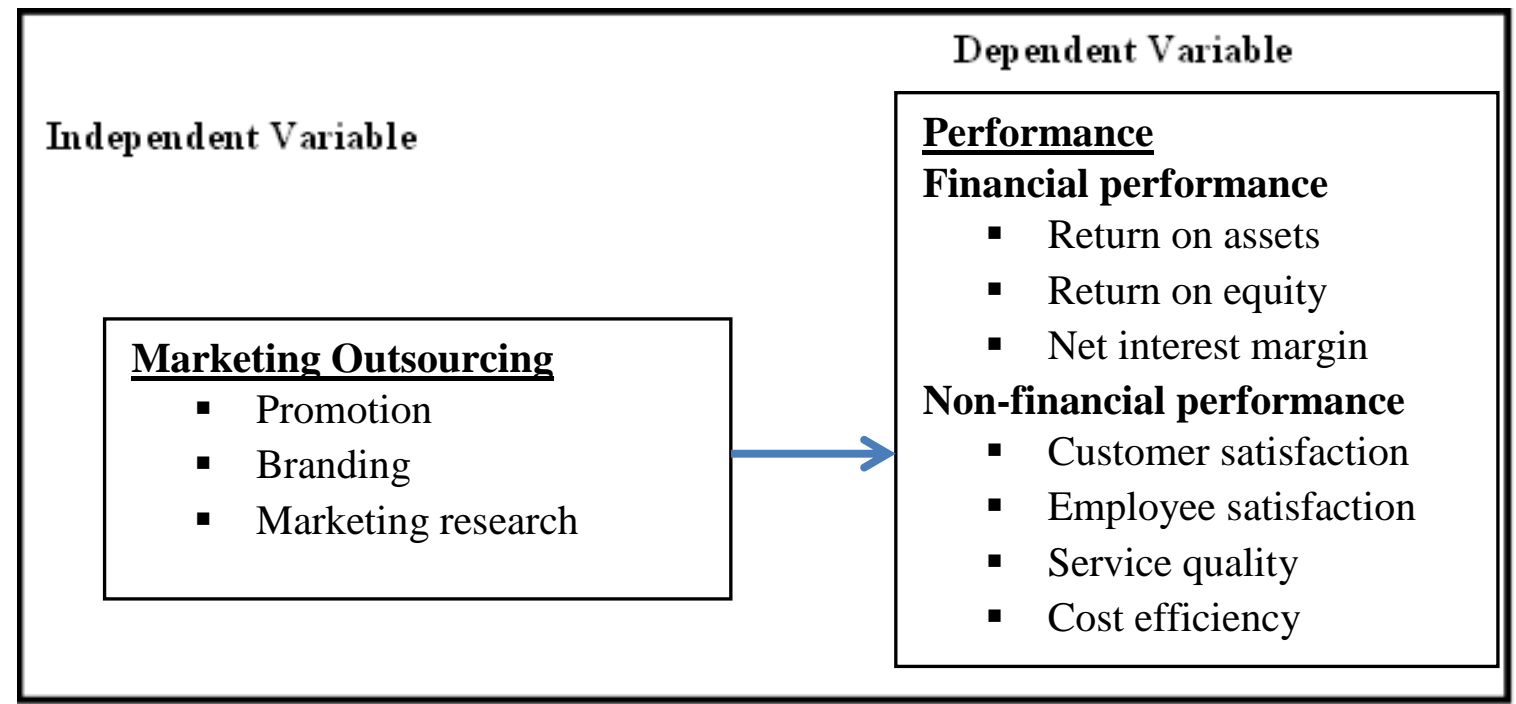

Figure 1: Conceptual Framework

\section{Research Methodology}

Saunders, Lewis and Thornhill (2009) argue that no single research design exists in isolation and that a combination of different designs in one study enables triangulation and increase the validity of the findings. Consequently, this study used a combination of cross-sectional explanatory and descriptive research designs. Explanatory research design is employed when a hypothesis as to why something is happening already exists (Mugenda \& Mugenda, 2003). Moreover, explanatory research establishes causal relationships between or among variables (Saunders, 2009; 2014). In this study, the researcher sought to establish the causal relationship between marketing outsourcing and performance of commercial banks in Kenya. Descriptive research design on the other hand enables the researcher to capture a population's attributes and test hypotheses, and describe the current relationship of the variables under study in their context without manipulating them (Cooper \& Schindler, 2003).

In statistical analysis, different models can be used to analyse quantitative data depending on the nature of variables. In this study, regression analysis was used since the dependent variable (performance) was continuous (Field, 2009). The regression coefficient of determination $\left(R^{2}\right)$ was used to determine the significant factors at 95 per cent confidence level $(p<0.05)$. To determine the strength of the relationship between marketing outsourcing and performance of commercial banks, linear regression equation for predicting $\boldsymbol{P}_{\boldsymbol{i}}$ (performance of commercial banks) was expressed as follows: 
$P_{i}=\beta_{0}+\beta_{1} M O+\epsilon_{i}$

Where;

$\boldsymbol{P}_{\boldsymbol{i}}=$ Performance of commercial banks in Kenya

$\boldsymbol{\beta}_{\mathbf{0}}=$ Constant $(\mathrm{Y}$ - intercept)

$\boldsymbol{B}_{1}=$ Beta coefficient

MO = Marketing Outsourcing

$\boldsymbol{\varepsilon}_{\mathrm{i}}=$ error term

The coefficient path $\beta_{1}$ and $\varepsilon$ measured the effect of $\mathrm{MO}$ on $P_{i}$. The significance of the beta values ( $\beta$ ) was used to test the hypothesis.

\section{Target Population}

The target population for this study was thirty two (32) commercial banks at their headquarters in Nairobi Capital City following qualifying criteria that required banks to be engaged in marketing outsourcing and should not be either under statutory management or receivership for them to be included in the final study. A pilot study led to the exclusion of 11 from the 43 commercial banks in Kenya; one had been liquidated, three were under statutory management while seven failed to participate in the pilot study to help determine whether they were engaged in marketing outsourcing or not. Respondents were purposely selected from four departments: Marketing, Information Technology, Human Resource Management and Operations, thus constituting a total respondent base of 128. Kothari (2004) and Mugenda \& Mugenda (2003) observe that when the universe/population is small, it is of no use resorting to sampling, hence a survey of all the 128 managers. Table 1 gives detailed information on the target population.

Table 1: Summary of the Distribution of Target Population

\begin{tabular}{|c|c|c|c|c|}
\hline Category & Frequency & $\begin{array}{l}\text { Number of } \\
\text { Departments }\end{array}$ & $\begin{array}{l}\text { Number } \\
\text { Respondents }\end{array}$ & Percentage \\
\hline Large & 7 & 4 & 28 & 21.9 \\
\hline Medium & 12 & 4 & 48 & 37.5 \\
\hline Small & 13 & 4 & 52 & 40.6 \\
\hline Total & 32 & & 128 & 100 \\
\hline
\end{tabular}

Source: Researcher (2018)

\section{Data Collection Instruments, Validity and Reliability}

The study used both primary and secondary data collection tools. Primary data were obtained from the respective banks using questionnaires that contained closed-ended items to enable collection of quantitative data. Secondary data were obtained from banks' annual reports, Central Bank of Kenya annual reports and from the Nairobi Securities Exchange.

The study ensured that instruments of data collection accurately measured the constructs of study variables by carrying out a pilot study. Field (2009) and Huang, Lee, Kim \& Judge (2013) contend that pilot testing is necessary for establishing whether data collection instruments possess face and 
INTERNATIONAL JOURNAL OF ACADEMIC RESEARCH IN BUSINESS AND SOCIAL SCIENCES

Vol. 8, No. 12, Dec, 2018, E-ISSN: 2222-6990 C 2018 HRMARS

content validity. Mugenda and Mugenda (2003) argue that content validity can be reinforced by seeking opinions of experts or professionals. Content and construct validities were also ascertained by ensuring that the study objective was backed up by theoretical frameworks.

Internal consistency (reliability) of the instrument items was ensured by use of Cronbach Alpha Coefficient (Gay \& Airasian, 2000). Cronbach Alpha coefficients range from zero to one and a good measure of reliability is considered to be where the alpha coefficient of predictor variables ranges from 0.7 and above (Ehlers, 2000). In this research, marketing outsourcing had a Cronbach Alpha Coefficient of 0.96 which was quite reliable.

\section{Data Analysis}

Quantitative data were analysed using descriptive statistics such as frequencies, means, percentages and standard deviations; and inferential statistics such as linear regression and correlation analysis in Stata version 12.1 Software (statistical package). The coefficient of determination was used to measure the amount of variation in the dependent variable (bank performance) explained by the independent variable. To make reliable inferences from the data, all the statistical tests were subjected to tests of significance at alpha level of $\alpha=0.05$.

\section{Research Findings and Discussion}

Analysis of the Response Rate

The researcher sought to establish the response rate of the study and Table 2 shows the results.

Table 2: Response Rate

\begin{tabular}{lcc}
\hline Response Rate & Frequency & Per cent \\
\hline Filled and returned & 76 & 59.4 \\
Non-returned & 52 & 40.6 \\
Total & $\mathbf{1 2 8}$ & $\mathbf{1 0 0}$ \\
\hline
\end{tabular}

Source: Survey Data (2017)

The researcher distributed 128 questionnaires out of which 76 were filled and returned by the respondents representing an overall successful response rate of 59.4 per cent. Fifty two (52) questionnaires (40.6 per cent) were never returned. With regard to the suitability of the above response rate in making generalisations and inferences, Wimmer and Dominick (2006) observe that a response rate of 21-70 per cent is acceptable for self-administered questionnaires as it guarantees accuracy and minimises bias while Rogelberg and Stanton (2007) posit that cross-sectional studies of survey design conducted at the individual level are expected to yield a response rate of 50 per cent. Therefore, the response rate of 59.4 per cent was deemed appropriate for achieving the objective of the study and making generalisations on the entire commercial banking sector. 
INTERNATIONAL JOURNAL OF ACADEMIC RESEARCH IN BUSINESS AND SOCIAL SCIENCES

Vol. 8, No. 12, Dec, 2018, E-ISSN: 2222-6990 C 2018 HRMARS

\section{Quantitative Data Analysis}

\section{Descriptive Statistics for Marketing Outsourcing}

Marketing outsourcing was measured using three indicators namely; promotion, branding and marketing research. Respondents were asked to rate marketing outsourcing indicators on the Likert scale of 1 to 5, where 5 represents; "To a very great extent" and 1 "Not at all". Means and standard deviations were then computed for the variable as given in Table 3.

Table 3: Descriptive Statistics for Marketing Outsourcing

\begin{tabular}{|c|c|c|c|c|c|}
\hline Marketing Outsourcing & $\mathbf{N}$ & Min & Max & Mean & $\begin{array}{l}\text { Std. } \\
\text { Dev. }\end{array}$ \\
\hline \multicolumn{6}{|l|}{ Promotion } \\
\hline The bank uses a marketing agency for its advertisements & 76 & 1 & 5 & 3.8 & 1.346 \\
\hline External vendors are used by the bank for sales promotion & 76 & 1 & 5 & 3.6 & 1.337 \\
\hline The Relationship Manager works in liaison with marketing agencies & 76 & 1 & 5 & 3.7 & 1.167 \\
\hline There is a budget for engaging the services of marketing agencies & 76 & 1 & 5 & 4.2 & 1.154 \\
\hline $\begin{array}{l}\text { The bank benefits from the resources and experience of the promotion } \\
\text { agency }\end{array}$ & 76 & 1 & 5 & 4.0 & 1.161 \\
\hline Aggregate Score & & & & 3.9 & 1.233 \\
\hline \multicolumn{6}{|l|}{ Branding } \\
\hline Specialist vendors are used in corporate branding & 76 & 1 & 5 & 4.0 & 1.168 \\
\hline Specialist vendors are engaged in product branding & 76 & 1 & 5 & 4.0 & 1.202 \\
\hline Strong branding by specialist companies improves product's visibility & 76 & 1 & 5 & 4.2 & 0.995 \\
\hline $\begin{array}{l}\text { Use of branding specialists improves customer impression on the bank as } \\
\text { well as its products }\end{array}$ & 76 & 1 & 5 & 4.0 & 1.060 \\
\hline Strong branding attracts more customers & 76 & 1 & 5 & 4.4 & 0.936 \\
\hline Strong branding enhances customer loyalty & 76 & 1 & 5 & 4.2 & 1.027 \\
\hline There is a budget for engaging the services of branding specialists & 76 & 1 & 5 & 4.1 & 1.251 \\
\hline Aggregate Score & & & & 4.1 & 1.091 \\
\hline \multicolumn{6}{|l|}{ Marketing Research } \\
\hline The bank uses specialist marketing vendors to conduct marketing research & 76 & 1 & 5 & 3.8 & 1.181 \\
\hline The bank benefits from the resources of the specialist marketing agencies & 76 & 1 & 5 & 3.9 & 1.182 \\
\hline Marketing research is time-consuming for in-house staff & 76 & 1 & 5 & 3.6 & 1.132 \\
\hline $\begin{array}{l}\text { Cost-efficiency is a major factor in engaging the services of specialist } \\
\text { marketing agencies }\end{array}$ & 76 & 1 & 5 & 4.2 & 1.023 \\
\hline $\begin{array}{l}\text { Marketing agencies are more flexible in responding to the environmental } \\
\text { changes }\end{array}$ & 76 & 1 & 5 & 3.8 & 0.805 \\
\hline $\begin{array}{l}\text { The experience of marketing agencies is quite beneficial to the bank in } \\
\text { responding to emerging issues in banking }\end{array}$ & 76 & 1 & 5 & 3.8 & 1.070 \\
\hline $\begin{array}{l}\text { There is a budget for engaging the services of specialist marketing } \\
\text { agencies }\end{array}$ & 76 & 1 & 5 & 4 & 1.130 \\
\hline Aggregate & & & & 3.9 & 1.075 \\
\hline
\end{tabular}

Source: Survey Data (2017) 
Table 3 shows that the overall aggregated mean score for marketing processes outsourcing was 4.0 on the five-point Likert scale with a standard deviation of 1.133. This result shows that respondents were in concurrence that outsourcing marketing processes affects performance of commercial banks. Among the studied outsourced marketing processes, branding was the most outsourced with an aggregate mean score of 4.1 and a standard deviation of 1.091. Respondents strongly agreed with the statements that; Strong branding by specialist marketing agencies improves product's visibility (Mean=4.2; SD=0.995); improves customer impression on the bank as well as its products (Mean=4.0; $\mathrm{SD}=1.060$ ); attracts more customers (Mean=4.4; $\mathrm{SD}=0.936$ ); and enhances customer loyalty (Mean=4.2; SD=1.027). Respondents also supported the statements that outsourcing marketing leads to cost efficiency (Mean=4.2; 1.023); and access to resources and experience of marketing agencies (Mean=4.0; 1.161).

These findings support the findings of Chumba, Chepkwony and Tum (2015) whose study on the effect of outsourcing marketing services on performance of manufacturing companies established a positive and significant effect on firm performance. These findings are also corroborated by the observations of Burden and $\mathrm{Li}$ (2005) that marketing outsourcing improves an organisation's performance by improving its market positioning, reducing costs, and improving overall quality.

\section{Descriptive Statistics for Bank Performance}

This domain comprised of non-financial performance and financial performance. However, both domains were Likert type with five points which easily allowed for comparability.

\section{Non-financial Performance}

This performance measure had four domains: customer satisfaction, employee satisfaction, service quality, and cost efficiency. Respondents were required to indicate the extent to which they agreed or disagreed with the statements regarding the influence of marketing outsourcing on non-financial performance of commercial banks; where 5 represented "Strongly agree" while 1 represented "Strongly disagree". The descriptive statistics for each of these items are reported in Table 4. 
INTERNATIONAL JOURNAL OF ACADEMIC RESEARCH IN BUSINESS AND SOCIAL SCIENCES

Vol. 8, No. 12, Dec, 2018, E-ISSN: 2222-6990 @ 2018 HRMARS

Table 4: Descriptive Statistics: Non-financial Performance

\begin{tabular}{|c|c|c|c|c|c|}
\hline Non-financial Performance & $\mathbf{N}$ & Min & Max & Mean & $\begin{array}{l}\text { Std. } \\
\text { Dev. }\end{array}$ \\
\hline \multicolumn{6}{|l|}{ Customer Satisfaction } \\
\hline Faster resolution of customer issues & 76 & 1 & 5 & 3.9 & 0.925 \\
\hline Enhances customer loyalty/retention & 76 & 2 & 5 & 3.9 & 0.896 \\
\hline High conversion rate of potential customers & 76 & 2 & 5 & 3.9 & 0.975 \\
\hline Increased sales volumes & 76 & 1 & 5 & 4.0 & 1.013 \\
\hline Increased market share & 76 & 2 & 5 & 4.1 & 0.928 \\
\hline More referrals from existing customers & 76 & 2 & 5 & 4.1 & 0.950 \\
\hline Aggregate Score & & & & 4.0 & 0.947 \\
\hline \multicolumn{6}{|l|}{ Employee Satisfaction } \\
\hline Efficiency in performance of duties & 76 & 2 & 5 & 4.0 & 1.052 \\
\hline Heightened level of innovativeness and creativity & 76 & 2 & 5 & 4.0 & 0.923 \\
\hline $\begin{array}{l}\text { Effectiveness in achieving individual as well as organisational } \\
\text { objectives/goals }\end{array}$ & 76 & 2 & 5 & 3.9 & 0.903 \\
\hline Low staff turn-over rates & 76 & 1 & 5 & 3.9 & 0.997 \\
\hline Consumption of bank's products and services by employees & 76 & 1 & 5 & 3.6 & 1.172 \\
\hline Aggregate Score & & & & 3.9 & 1.009 \\
\hline \multicolumn{6}{|l|}{ Service Quality } \\
\hline Reliability (dependability and accuracy) of service provision & 76 & 1 & 5 & 4.1 & 1.037 \\
\hline Quality assurance through competence, credibility and courtesy of staff & 76 & 1 & 5 & 4.1 & 0.991 \\
\hline Provision of requisite physical facilities & 76 & 1 & 5 & 3.8 & 1.004 \\
\hline Responsiveness to customer needs & 76 & 2 & 5 & 4.0 & 1.102 \\
\hline Security of data and products & 76 & 2 & 5 & 3.8 & 1.060 \\
\hline Aggregate Score & & & & 4.0 & 1.039 \\
\hline \multicolumn{6}{|l|}{ Cost Efficiency } \\
\hline Reduction in operational costs & 76 & 1 & 5 & 3.4 & 1.298 \\
\hline $\begin{array}{l}\text { Elimination of costs associated with installation of infrastructure such as } \\
\text { security equipment }\end{array}$ & 76 & 1 & 5 & 3.5 & 1.397 \\
\hline Allows management and staff to concentrate on their core business & 76 & 1 & 5 & 4.4 & 0.913 \\
\hline $\begin{array}{l}\text { Time saving thus allowing internal staff to focus on their primary } \\
\text { responsibilities }\end{array}$ & 76 & 1 & 5 & 4.2 & 0.863 \\
\hline Aggregate Score & & & & 3.9 & 1.118 \\
\hline Overall aggregate Score & & & & 3.95 & 1.028 \\
\hline
\end{tabular}

Source: Survey Data (2017)

Results of Table 4 show that the aggregate mean score for non-financial performance was 3.95 with a standard deviation of 1.028 . This implies that the respondents were in agreement that marketing 
outsourcing influences the soft performance of commercial banks. From the descriptive statistics, it is apparent that customer satisfaction (Mean=4.0; $\mathrm{SD}=0.947$ ) and service quality (Mean=4.0; $\mathrm{SD}=1.039$ ) are the major benefits of marketing outsourcing in commercial banks. It is also evident from the descriptive statistics that marketing outsourcing in commercial banks improves the efficiency and effectiveness of the management by allowing them to concentrate on their core business (Mean=4.4; SD=0.913), contributes to increased market share (Mean=4.1;0.928) arising from customer satisfaction; improves quality assurance (Mean=4.1; SD=0.991), and enhances effectiveness of employees in achieving individual as well as organisational goals (Mean=3.9; $\mathrm{SD}=0.903)$.

This finding supports the assertions of various proponents of business processes outsourcing, among which is marketing, who link it with numerous performance outcomes to organisations such as enabling them to shift focus to their core business and strategic issues thus handing off non-core processes to vendors (Hamel \& Prahalad, 1994; Handfield, 2006; Mclvor, 2008; Barako \& Gatere, 2008; Ghikas, 2012; Awino \& Mutua, 2014). Additionally, Yang, Kim, Nam and Min (2007); Mclvor (2008); Lee \& Kim (2010) observe that business processes outsourcing provides organisations with many benefits that include but not limited to: minimising workload of employees thus improving their productivity, attaining financial economies through cost management, access to new technologies and specialised expertise; achieve competitive advantage, productivity, flexibility, speed, and innovation in developing business applications.

\section{Financial Performance}

This section had three indicators: return on assets (ROA), return on equity (ROE) and net interest margin (NIM). Respondents were required to rate on the Likert scale of 1 to 5 the perceived financial performance of their banks relative to marketing outsourcing on the basis of the criteria below:

\section{(i) Return on Assets}

On a scale of $1-5$, rate the performance of your bank on return on assets (ROA) for the indicated periods (2013-2015) (where: 1= Very unsatisfactory (ROA less than 1\%); 2= Unsatisfactory (ROA 1.1 2.0\%); 3= Average (ROA 2.1 - 3.0\%); 4= Satisfactory (ROA 3.1 - 4.0\%); 5= Very satisfactory (ROA above $4 \%)$.

\section{(ii) Return on Equity}

On a scale of $1-5$, rate the performance of your bank on return on equity (ROE) for the indicated periods (2013-2015) (where: 1= Very unsatisfactory (ROE less than 10\%); 2= Unsatisfactory (ROE 11 15\%); 3= Average (ROE 16 - 20\%); 4= Satisfactory (ROE 21 - 25\%); 5= Very satisfactory (ROE above $25 \%)$.

\section{(iii) Net Interest Margin}

On a scale of $1-5$, rate the performance of your bank on net interest margin (NIM) for the indicated periods (2013-2015) (where: 1= Very unsatisfactory (NIM less than 5\%); 2= Unsatisfactory (NIM 5.1 - 
INTERNATIONAL JOURNAL OF ACADEMIC RESEARCH IN BUSINESS AND SOCIAL SCIENCES

Vol. 8, No. 12, Dec, 2018, E-ISSN: 2222-6990 @ 2018 HRMARS

7.0\%); 3= Average (NIM 7.1 - 9.0\%); 4= Satisfactory (NIM 9.1 - 11\%); 5= Very satisfactory (NIM above $11 \%)$.

The descriptive statistics for each of the items are reported in Table 5.

Table 5: Descriptive Statistics: Financial Performance

\begin{tabular}{llllll}
\hline Financial Performance & N & Min & Max & Mean & Std. Dev. \\
\hline Return on Assets & & & & & \\
2016 & 76 & 1 & 5 & 3.6 & 1.073 \\
2015 & 76 & 2 & 5 & 3.5 & 0.796 \\
2014 & 76 & 2 & 5 & 3.5 & 0.812 \\
2013 & 76 & 2 & 5 & 3.5 & 0.854 \\
Aggregate Score & & & & $\mathbf{3 . 5}$ & $\mathbf{0 . 8 8 4}$ \\
\hline Return on Equity & & & & & \\
2016 & 76 & 1 & 5 & 3.6 & 1.100 \\
2015 & 76 & 1 & 5 & 3.6 & 1.000 \\
2014 & 76 & 1 & 5 & 3.6 & 0.889 \\
2013 & 76 & 1 & 5 & 3.6 & 0.931 \\
Aggregate Score & & & & $\mathbf{3 . 6}$ & $\mathbf{0 . 9 8}$ \\
\hline Net Interest Margin & & & & & \\
2016 & 76 & 1 & 5 & 3.3 & 1.231 \\
2015 & 76 & 1 & 5 & 3.3 & 1.066 \\
2014 & 76 & 2 & 5 & 3.6 & 0.988 \\
2013 & 76 & 2 & 5 & 3.6 & 1.045 \\
Aggregate Score & & & & $\mathbf{3 . 5}$ & $\mathbf{1 . 0 8 3}$ \\
\hline Overall Aggregate Score & & & & $\mathbf{3 . 5 3}$ & $\mathbf{0 . 9 8 2}$ \\
\hline Surce Sur
\end{tabular}

Source: Survey Data (2017)

The overall aggregate mean score for financial performance was 3.53 with a standard deviation of 0.982. The mean score of 3.53 on the Likert scale indicates that the respondents attributed marketing outsourcing to financial performance of commercial banks in Kenya. From the three measures of financial performance used in the study, marketing outsourcing appeared to contribute slightly more to return on equity (Mean=3.6; $S D=0.980$ ) compared to return on assets (Mean=3.5; $S D=0.884$ ) and net interest margin (Mean=3.5; SD=1.083).

In conclusion, it can be deduced that following the balanced scorecard approach to the measurement of organisational performance, findings from both non-financial as well as financial measures show that marketing outsourcing is linked to performance of commercial banks in Kenya with greater effect being on non-financial performance. These findings support those of a study by Fritsch and Wullenweber (2005) which analysed 137 business process outsourcing ventures at 254 German banks and found that the outsourcer's financial performance in terms of profitability and cost efficiency was increased significantly compared to industry peers without business process outsourcing. 
INTERNATIONAL JOURNAL OF ACADEMIC RESEARCH IN BUSINESS AND SOCIAL SCIENCES Vol. 8, No. 12, Dec, 2018, E-ISSN: 2222-6990 @ 2018 HRMARS

\section{Inferential Statistics: Regression Analysis and Hypothesis Testing}

The study tested the following hypothesis with regard to the research objective;

$\mathbf{H}_{01}$ : Marketing Outsourcing has no effect on performance of commercial banks in Kenya.

Table 6 Results of Hypothesis Testing

\begin{tabular}{|c|c|c|c|}
\hline Dependent Variable=Bank Performance & \multicolumn{3}{|c|}{ Regression results } \\
\hline & Coefficients & t-statistic & P-value \\
\hline Marketing Outsourcing & $0.122 * * *$ & 15.84 & 0.000 \\
\hline Constant & $1.572 * * *$ & 46.48 & 0.000 \\
\hline $\begin{array}{l}* * \text { significa } \\
* * * \text { sigr }\end{array}$ & $\begin{array}{l}5 \text { per cent } \\
\text { at } 1 \text { per cent }\end{array}$ & & \\
\hline
\end{tabular}

$P_{i}=\beta_{0}+\beta_{1} M O$

$P_{i}=1.572+0.122$

The results in Table 6 show that the coefficient of outsourcing marketing is 0.122 with a t statistic of 15.84 and a corresponding $p$-value of 0.000 as shown in Table 6 . Since the $p$-value is less than 0.05 , the calculated $t$ is greater than the critical value at five per cent level of significance. Therefore, the null hypothesis is rejected implying that outsourcing marketing has statistically significant positive effect on performance of commercial banks in Kenya. The magnitude of the coefficient of outsourcing marketing processes is 0.122 implying that one unit change in the score of outsourcing marketing processes leads to 0.122 units change in the score of bank performance.

The positive relationship between marketing outsourcing and bank performance is supported by the findings of Chumba, Chepkwony, Tum (2015) and Alexander (2012) who established a significant relationship between outsourcing of marketing and performance. The finding also agrees with the observations of Burden and Li (2005) that marketing outsourcing affects organisational performance by improving its market position, reducing costs, and improving overall quality. They observe that marketing outsourcing allow organisations to gain new knowledge, access new markets, establish traction in the industry, reduce the threats and barriers of competition, enhance resource efficiency, and acquire new skills. Ibid (2005) also observe that outsourcing of marketing frees up resources for re-allocation toward core business activities to better serve organisational goals.

\section{Conclusion and Recommendations}

Regarding the effect of outsourcing marketing on performance of commercial banks in Kenya, the descriptive statistics showed that marketing outsourcing had an overall aggregate mean of 4.0 on the five-point Likert scale and a standard deviation of 1.133 meaning that respondents were of the view that it was positively linked to performance of commercial banks in Kenya. Results of the regression analyses revealed that marketing outsourcing had a beta value of 0.122 and a $p$-value of 0.000 implying that outsourcing of marketing had a statistically significant positive effect on performance of commercial banks in Kenya. 
In view of the above findings, the study therefore recommends that commercial banks' top management should develop policies that support mainstreaming marketing outsourcing strategy especially in corporate branding which was deemed instrumental in attracting more customers, enhancing customer loyalty, and improving customer's impression on the bank generally as well as its products; aspects that translate into increased market share thus enhancing financial performance of commercial banks. To avoid the threats associated with marketing outsourcing, rigor should be put when selecting vendors by ensuring thorough vetting process. In addition, commercial banks, through the marketing department, should ensure proper and healthy management of the outsourcee-outsourcer relationship.

\section{Contribution of the Study}

The findings of this study make theoretical contribution to strategic management field by establishing positive linkage between marketing outsourcing and performance of commercial banks. In addition, the study validates the propositions of the core competence theory, resource based view and dynamic capabilities view with regard to the import of outsourcing in influencing organizational performance. Furthermore, investigation of the effect of marketing outsourcing on performance of commercial banks contributed to the extant literature broadly on the relationship between outsourcing and organizational performance and specifically on the nexus between marketing outsourcing and performance of commercial banks; a contribution that is lacking in previous studies. Contextualisation of the study showed business processes outsourcing, among which is marketing outsourcing, as a management strategy is gaining currency in developing countries like Kenya. This study also led to the development of a conceptual framework that can be adopted or adapted by other researchers in different contexts and industries.

\section{Suggestions for further Research}

Future research can follow the following research streams; Comparative study on marketing outsourcing in public and private commercial banks; since this study was cross-sectional in nature, a longitudinal study would be instrumental in tracking real-time effects of marketing outsourcing on performance over a period of time to determine its stability and sustainability as a strategic management tool in the long-run. Different conceptualization of marketing outsourcing can be adopted to establish its effect on organizational performance in the same or different industries. 
INTERNATIONAL JOURNAL OF ACADEMIC RESEARCH IN BUSINESS AND SOCIAL SCIENCES

Vol. 8, No. 12, Dec, 2018, E-ISSN: 2222-6990 @ 2018 HRMARS

\section{References}

AIB Capital Ltd (2017). Banking sector valuation update. LXM LLP, USA.

Alexander, P. (2012). Outsourcing Public Relations services and outlining a profile of $P R$ practitioners:Companies and $P R$ agencies in Cluj-Napoc. PhD thesis summary.

Awino, Z.B., \& Mutua, J.M. (2014). Business process outsourcing strategy and performance of Kenyan state corporations. Journal of Emerging Trends in Economics and Management Sciences (JETEMS), 5(7), 37-43.

Bank of China Institute of International Finance (2017). Global banking industry outlook. Annual Report, (2).

Barako, D.G., \& Gatere, P.K. (2008). Outsourcing practices of the Kenyan banking sector. African Journal of Accounting, Economics, Finance and Banking Research, 2(2), 37-50.

Barney, J. (1991). Firm resources and sustained competitive advantage. Journal of Management, $17(1), 99-120$.

Barthélemy, J., \& Geyer, D. (2005). An empirical investigation of IT outsourcing versus quasioutsourcing in France and Germany. Information \& Management, 42(4), 533-542.

Burden, W., \& Li, M. (2005). Circumstantial factors and institutions' outsourcing decisions on marketing operations. Sport Marketing Quarterly, 14, 125-31.

Central Bank of Kenya. Bank annual supervision report (2017). Nairobi. Retrieved from http://www.centralbank.go.ke.

Central Bank of Kenya. Bank annual supervision report (2016). Nairobi. Retrieved from http://www.centralbank.go.ke.

Chumba, R.K.B., Chepkwony, P.K., \& Tum, M.J. (2015). Effect of business process outsourcing services on performance of manufacturing companies in Eldoret and Nandi Hills, Kenya. International Journal of Business Management Review, 3(3), 46-61.

Coombs, J.G., Crook, T.R., \& Shook, C.L. (2005). The dimension of organisation performance and its implications for strategic management research and research methodology in strategy and management. San Diego. Elsevier, 259-286.

Cooper, D.R., \& Schindler, P. S. (2003). Business research methods ( $8^{\text {th }}$ ed.). McGraw-Hill Irwin: Boston, USA.

Cytonn Investments (2017). Kenya banking sector report.

Datamonitor (2004e). Offshore call centre outsourcing: What threats to jobs? www.datamonitor.com.

Ehlers, M.B. (2000). Residential based business: An alternative location. Decision for SME's. Unpublished Doctor of Commerce thesis; University of Pretoria.

Ernest \& Young Global Ltd (2018; 2017). Global banking outlook. UK.

Field, A. (2009). Discovering statistics using SPSS ( $2^{\text {nd }}$ ed.). SAGE: London, UK.

Fritsch, M., \& Wüllenweber, K. (2007). Firm-level determinants of business process outsourcing decisions. IRMA 2007, Vancouver, Canada.

Gannon, B. (2010). Proposing a methodology for the outsourcing of the marketing function for SMEs and MEs. Unpublished MBSI Thesis. Galway-Mayo Institute of Technology.

Gay, L.R., \& Airasian, P. (2000). Educational research: Competencies for analysis and application ( $6^{\text {th }}$ ed.). U. $p p e r$ Saddle River, NJ: Prentice Hall. 
INTERNATIONAL JOURNAL OF ACADEMIC RESEARCH IN BUSINESS AND SOCIAL SCIENCES

Vol. 8, No. 12, Dec, 2018, E-ISSN: 2222-6990 @ 2018 HRMARS

Ghikas, N.N. (2012). Implementation of business process outsourcing strategy in Standard Chartered Bank, Kenya, Ltd. Unpublished MBA project. Nairobi: University of Nairobi.

Gilley, K.M., McGee, J.E., \& Rasheed, A.A. (2004). Perceived environmental dynamism and managerial risk aversion as antecedents of manufacturing outsourcing: The moderating effects of firm maturity. Journal of Small Business Management, 42(2), 117-133.

Glassman, D. (2000). IT outsourcing and shareholder value. Evaluation, 2(5), 1-8.

Handfield, (2006). Human resource management: $A$ contemporary approach $\left(5^{\text {th }}\right.$ ed.), London, Prentice Hall.

Huang, H., Lee, D., Kim, M.K., Kim, S.K., \& Judge, L.W. (2013). Service quality and satisfaction perspectives at the 2011 International Amateur Athletic Federation (IAAF) World Championships. ICHPER-SD Journal of Research, 8(2), 39-44.

International Monetary Fund (2016; 2017). Performance of the banking industry. Annual Report.

Judge, W.Q., Naoumova, I., \& Douglas, T. (2009). Organisational capacity for change and firm performance in a transition economy. International Journal of Human Resource Management, 20, 1737-1752.

Kaplan, R.S., \& Norton, D.P. (1992). The balanced scorecard measures that drive performance. Harvard Business Review, 70(1), 71-79.

Kiiru, D.M. (2015). Strategic human resource management practices and performance of parastatals in Kenya. Doctoral dissertation. Kenyatta University.

Kliem, R.L. (1999). Managing the risks of outsourcing agreements. Information Systems Management, Summer 91-93.

Kothari, C.R., \& Garg, G. (2014). Research Methodology: Methods\& techniques (3 ${ }^{\text {rd }}$ ed.). New Age International Publishers, New Delhi, India.

Kothari, C.R. (2004). Research Methodology: Methods and Techniques. New Age International (P) Ltd. Publishers.

KPMG, (2017). Non-performing loans in Europe. Retrieved from kpmg.com/ecb.

Kumar, N. (2005). Export of software and business process outsourcing from developing countries: Lessons from the India experience. Asia-Pacific Trade and Investment Review, 1(1), 91-110.

Lee, R.P., Kim, D. (2010). Implications of service processes outsourcing on firm value. Industrial Marketing Management, 39, 853-861.

Ljungquist, U. (2007). Core competency beyond identification: Presentation of a model. Management Decision, 45(3), 393-402.

Mata, F.T., Fuerst, W.L., \& Barney, J. B. (1995). Information technology and sustainable competitive advantage: A resource based view analysis. MIS Quarterly Review, 19(4), 487-495.

Mclvor, R. (2008). The outsourcing process: Strategies for evaluation and management. Cambridge: Cambridge University Press.

Mugenda, A.G., \& Mugenda, O.M. (2003). Readings in research methods: Quantitative and qualitative approaches. African Centre for Technology Studies (ACTS), Nairobi.

Mugenda, A.G., \& Mugenda O.M. (1999). Research methods: Quantitative and qualitative approaches. ACTS Press, Nairobi. 
INTERNATIONAL JOURNAL OF ACADEMIC RESEARCH IN BUSINESS AND SOCIAL SCIENCES

Vol. 8, No. 12, Dec, 2018, E-ISSN: 2222-6990 C 2018 HRMARS

Park, J.E., Lee, S., \& Morgan, R.M. (2011): A negative side of outsourcing marketing functions and market-based learning process, Journal of Strategic Marketing, 9(5), 471-486.

Prahalad, C.K., \& Hamel, G. (1990; 1994). The core competence of the corporation. Harvard Business Review, 68(3), 79-91.

Quinn, J.B., \& Hilmer, F.G. (1994). Strategic outsourcing. Sloan Management Review, 35(4), 43-55.

Rogelberg, S., \& Stanton, J. (2007). Understanding and dealing with organisational survey non -response. Organisational research methods, 10, 195-209.

Santos, J.B., \& Brito, A.I.A. (2012). Towards subjective measurement model of firm performance. Brazilians Administration Review, Special Issue.

Saunders, M., Lewis, P., \& Thornhill, A. (2013). Research methods for business students,

(6th ed.). Harlow: Prentice Hall Financial Times.

Saunders, M., Lewis, P., \& Thornhill, A. (2009). Research methods for business students, ( $5^{\text {th }}$ ed.). New Jersey: Prentice Hall: London.

Shimamoto, S., \& Redden, S. (2009). Outsourcing success factors: Sales and marketing. ZS Associates, Inc. USA.

Taylor, S.A. \& Baker, T.L. (1994). An assessment of the relationship between service quality and customer satisfaction in the formation of consumers' purchase intentions. Journal of Retailing, 70(2), 163-178.

Teece, D.J., Pisano G., \& Shuen A. (1997). Dynamic capabilities and strategic management. Strategic Management Journal, 18(7), 509-533.

Teece, D.J., \& Pisano G. (1994). The dynamic capabilities of firms: An introduction. Industrial and Corporate Change, 3(3), 537-556.

Waiganjo, E., Mukulu, E., \& Kahiri, J. (2012). Relationship between strategic human resource management and firm performance of Kenya's corporate organisations. International Journal of Humanities and Social Science 2(1), 63- 68.

Wimmer, R.D., \& Dominick, J. R. (2006). Mass media research: An introduction, (6th ed.). Belmont, CA: Wadsworth Publishing Company.

World Bank (2017). Performance of the banking industry. Annual Report.

Yang, C., \& Huang, J. (2010). A decision model for IS outsourcing. International Journal of Information Management, 20(1), 225-239.

Yang, D.H., Kim, S., Nam, C., \& Min, J.W. (2007). Developing a decision model for business process outsourcing. Computers \& Operations Research, 34(12),3769-78.

Zuriekat, M., Salameh, R., \& Alrawashdeh, S. (2011). Participation in performance measurement systems and level of satisfaction. International Journal of Business and

Social Science, 2(8), 159-169. 